\title{
Hamadryas Baboon (Papio hamadryas hamadryas) Population Size and Their Distribution in Community Forest in Gasera District of Bale Zone, Southeast Ethiopia
}

\author{
Ahmed Abdela ${ }^{1,2}$ \\ ${ }^{1}$ School of Biodiversity and Natural Resource, Faculty of Agriculture and Natural Resource, Madda Walabu University, Bale Robe, Ethiopia \\ ${ }^{2}$ Department of Ecosystem \& Biodiversity Conservation, Madda Walabu University, Bale Robe, Ethiopia
}

Email address:

ahmedabdela5555gmail.com

\section{To cite this article:}

Ahmed Abdela. Hamadryas Baboon (Papio hamadryas hamadryas) Population Size and Their Distribution in Community Forest in Gasera District of Bale Zone, Southeast Ethiopia. American Journal of Life Sciences. Vol. 8, No. 5, 2020, pp. 157-164.

doi: 10.11648/j.ajls.20200805.21

Received: October 24, 2019; Accepted: April 29, 2020; Published: September 24, 2020

\begin{abstract}
The study on population size and distribution was carried out in community forest in the Gasera district of Bale zone south east of Ethiopia from February 2017 to January 2018. Hamadryas baboon population size and distribution has never been studied and determined by Gasera district. Therefore, this study was conducted to assess Hmadryas baboon (Papio hamadryas hamadryas) Population Size and their Distribution in Community forest in Gasera District of Bale Zone, Southeast Ethiopia. Materials used for this study were GPS to plot study area, camera for scan sampling, Binocular to see a Hamadryas baboon from the distance, note pad, pen, pencil and was used to record data and video cameras was to insure hamadryas baboon counting. Assessing Population size and distribution of hamadryas baboon was estimated using the total count method at three counting sites by line transect. Data was analyzed by Chi-square test to compare sex and age structure of hamadryas baboon and T-test was used to compare wet and dry season population size of hamadryas baboon in each study site. The total number of individuals during wet season was 1199 and 1146 during the dry season. The average number of hamadryas baboon observed in the entire study area during both season was 1173 . There was no significant difference between wet and dry season $(\mathrm{x} 2=1.1978, \mathrm{df}=1, \mathrm{p}>0.05)$. During the wet season, the individual count from the study area was $16 \%$ adult male, $27 \%$ adult female, $12 \%$ sub adult male, $18 \%$ sub adult female, $10 \%$ juvenile male, $14 \%$ juvenile female, $3 \%$ infants. During the dry season, the individual count was $15.8 \%$ adult male, $28 \%$ adult female, $11.5 \%$ sub adult male, $18.5 \%$ sub adult female, $9 \%$ juvenile male, $14 \%$ juvenile female, $2.5 \%$ infants. The proportion of female hamdryas baboon was high in all age groups except infant in which identification of sex is difficult.
\end{abstract}

Keywords: Community Forest, Distribution, Gasera District, Hamadryas Baboon (Papio hamadryas hamadryas), Population Size

\section{Introduction}

\subsection{Background of the Study}

The study about wild animal population size, distribution, is important for their conservation and ensures their viability in their natural habitat. An understanding of the basic quantitative natural history of primate species is vital to their conservation [1]. Ethiopia possesses a diverse mammalian fauna of 320 species of 52 families [2], of which, 31 species are endemic [3]. The high level of endemism in the fauna of
Ethiopia is related to the large extent of the highlands, variations in temperature and rainfall in different habitats have led to the diversity of species [4]. Africa has the largest primate fauna and there are 175 species and sub-species of primates listed in Africa [5].

Hamadryas baboon was abundantly found in Egypt in recent past, however at present it is locally extinct from Egypt [6]. At present, it is highly restricted to certain areas of the ranging countries in the northeastern Africa and southwestern Arabia. The restricted geographical distribution may be due to habitat loss through agricultural expansion, 
deforestation affecting the food resources, human settlement in and around the habitats of the baboons, hunting for meat and biomedical research, conflict between the baboons and farmers [7]. Even though, the geographical distribution is limited to northeastern Africa and southwestern Arabia, hamadryas baboon is considered as a least concern [8]. The current distribution of hamadryas baboon in the eastern Ethiopia, Eritrea and Sudan, western Djibouti and Somalia, southwestern Saudi-Arabia and Yemen [8].

In Ethiopia hamadryas baboon lives in semi-desert areas of Awash National Park, particularly in Filwoha area [9]. The species occurs in Yangudi Rassa National Park, the Harar Wildlife Sanctuary, and a number of wildlife reserves in the lower Awash valley and in northern Eritrea [10].

Primates occupy a wide range of habitats, even though they are a relatively small order. In addition, they occupy a wide diversity of ecological niches [11]. Hamadryas baboon habitats require elevated sleeping sites usually as large trees or cliffs, where the baboons can spend their nights with a reduced threat of predation. Rarely, if ever, have baboons have been known to willingly sleep on the ground [12].

In Saudi-Arabia, hamadryas baboons are given food by people. However, the natural behavior of these baboons may change through time because they can access food resources easily without travelling long distances to search, locate and forage [13]. In Saudi-Arabia, hamadryas baboons are given food by people. However, the natural behavior of these baboons may change through time because they can access food resources easily without travelling long distances to search, locate and forage [13]. The hamadryas baboon eats fruit in captivity, although it is not a regular part of its diet in the wild. The hamadryas baboon is omnivorous and is adapted to its relatively dry habitat. During the wet seasons, the baboon feeds on a variety of foods, including blossoms, seeds, grasses, wild roots, and leaves from acacia trees [9]. During the dry season, the baboons eat leaves of the Dobera glabra (Saluadoraceae) and sisal leaves. Hamadryas baboons also eat insects, reptiles and small mammals.

The hamadryas baboon is listed on Appendix II to the Convention on International Trade in Endangered Species of Wild Flora and Fauna and export and import of this species is therefore subject to regulation under the Commonwealth Environment Protection and Biodiversity Conservation Act 1999 [14]. The IUCN listed this species as "least concern [15]. There are no major range-wide threats at present, although locally, it may be at risk through loss of habitat due to major agricultural expansion and irrigation projects [15].

To study the population size of Hamadryas baboon we used the total count method at three counting sites where their sleeping site is situated. Counting was made simultaneously early in the morning at 7:00-8:00pm and late afternoon at 5:00-6:00pm. To study the distribution of hamadryas baboon we divided the habitat of hamadryas baboon into the forest, Bush land, Grassland and agricultural area in both wet and dry season and count their number we take GPS lactation of their presence and introduce data into Arc GIS Arc Map to create the map of their distribution.

Data was analyzed by SPSS descriptive statistics as t-test to compare dry and wet season population size of hamadryas baboon and Chi-square test was used to show sex and age structure of Hamadryas baboon. Totally at each counting site 1146 and 1199 individuals of hamadryas baboon was counted during dry and wet season respectively. The average number of hamadryas baboon counted at three counting sites, namely walda jebsa, Burkitu and walda aboti in wote chimo cliffs was 1173.

\subsection{Statement of the Problems}

Primate populations, like those of other organisms, face the challenge of coping with the dynamics of their habitats because habitats are continually changing and primates must adapt to changes in order to survive; failure to adapt dooms species to extinction [16].

Primates that live in protected areas are intensively studied; however, those that live outside protected areas are less studied by primatologists [17]. There was no research that was conducted on hamadryas baboon population size and distribution in the Gasera district so their population trends were not known this has its own considerable impact on their conservation. Therefore the current study was aimed to investigate Hamadryas baboon (Papio hamadryas hamadryas) Population size and their Distribution in community forest of in the Gasera district of Bale zone south east Ethiopia.

\subsection{Significance of the Study}

This study provided information on the current status of Hamadryas baboon population size and their distribution in the study area. This is important for the proper conservation and Hamadryas baboon population management action as well.

The study provided information for stakeholders as government, nongovernmental organization, other institutions and local people to strengthen conservation activity in order to establish comfortable habitat for Hamadryas baboon wild insures their viability and sustainability.

The study was carried out on Hamadryas baboon population size and Distribution outside of the national park, though it will provide a base line data for other researchers that may carry out their further study in the study area.

\subsection{Objective of the Study}

\subsubsection{General Objectives}

The general objective of this study is Assessing Hamadryas baboon (Papio hamadryas hamadryas) Population Size and their Distribution in Community Forest in Gasera District of Bale Zone, Southeast Ethiopia.

\subsubsection{Specific Objectives}

1. To determine Hamadryas baboon population size in the 
Gasera community forest.

2. To describe the distribution of Hamadryas baboon in the study area.

\subsection{Research Questions}

1. What is the current population size of Hamadryas baboon in the study area?

2. What is the distribution of Hamadryas baboon in the study area?

\section{Methodology}

\subsection{Description of Study Area}

Gasera Community forests are located along the southeast parts of Ethiopia. Three villages, Wote Cimo and Balo Aminya and Gasera 01 kebele of the district own the community forest. They name the forest as, youth and elders association of Wote Chimo, Burkitu of Gasera and Wolda
Jebesa of Balo Aminya. It is located in Bale zone in the Gasera special district, about $60 \mathrm{~km}$ east of Robe town and $490 \mathrm{~km}$ southeast of Addis Ababa. The study area lies between the coordinates $7^{\circ} 21^{\prime} 56.7^{\prime \prime} \mathrm{E}$ and $40^{\circ} 11^{\prime} 04.2^{\prime \prime} \mathrm{N}$. The Wote chimo elders association forest is bordered by Nake Nagawo from the west and, Wote Chimo keble from south and east, Zeyfata from thenorth. Burkitu community forest is bordered by the Gasera town from south and Balo madada from the north, Wote chimo from the west and Wolda gebesa from the east. Wolda Gebesa is bordered by, Balo Habebe from the north, Balo Aminya from south and east, Burkitu from the west. The elevation of study area is $2339 \mathrm{~m}$ above the sea level. Gasera community forest is characterized by heterogeneous hilly terrain. Large portion of study area is valley floor, drained bottomland with different hills. The study area lies on the top edge of the Wabe river gorge. The high land is characterized by little flat and the low land is characterized by gentle slope. Totally, the community forest areas accounts for more than 234.674 hectare.

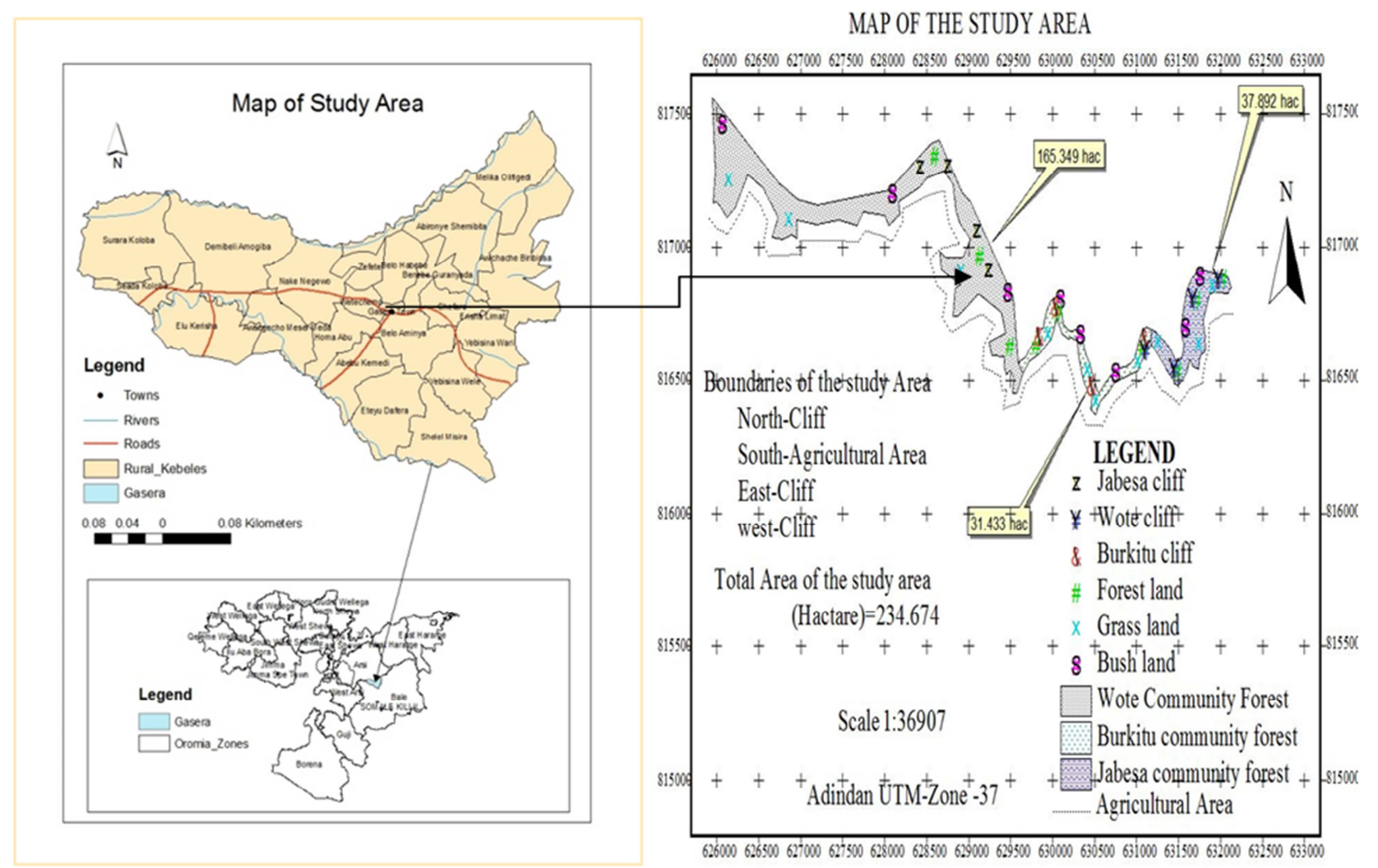

Figure 1. Location and Map of the study area.

\subsection{Materials}

During the survey, the researcher used the following material for the investigation. These were GPS, camera for scan sampling, binocular to see animals from distance, note pad and pen and pencil to record data during data collection and flash and Video camera.

\subsection{Data Collection Methodes}

Population size and distribution of Hamadryas baboon
To study and determine the population size of hamadryas baboon, a total count method has been used following methods of [18]. Total count along transect was carried out at three different counting sites, namely, Wote chimo, Burkitu and Wolda gebesa. Six transects were set in the three study sites, two in each site, each at averagely $2 \mathrm{~km}$ long, to cover the study area. An observation was made on foot simultaneously early in the morning at 6:00-7:00 a. m. and late afternoon from 5:00-6:00pm. Speed of travel along the strip transects was $1 \mathrm{~km} /$ hour by foot. To carry out direct 
count, six individuals were employed, excluding the researcher. Hence, two individuals were assigned to count at each counting sites when baboons were at their resting site. Usually hamadryas baboons stay at their sleeping cliffs late afternoon from 5:00-6:00am and leave their cliff to forage early in the morning around 6:00 a. m. [9].

Habitat suitability was assessed through repeated observation of the baboons ranging and travel patterns in search of forage resources on a daily basis [19]. Double counting was minimized following their behavior of movement and repeated observation of their video. Population density estimates were obtained by multiplying the product of density estimates with the observed mean group size [20]. For each group seen we recorded the group size and composition adult male, adult female, juvenile and infant [21].

The total population was estimated by multiplying the average group density estimates with the total area of suitable habitat at the study site [1].

$\mathrm{D}=$ Number of individuals in an area/ total area in $\mathrm{km}$.

\subsection{Data Analysis}

Data were analyzed using SPSS version 20.0 computer software. Accordingly, Chi-square test were used to compare sex and age structure of hamadryas baboon and t-test was used to compare the wet and the dry season population size and age structure of hamadryas baboon in each site.

\section{Result}

The result obtained during the survey period is given in the following three separate sections. The first section deals with a population size of hamadryas baboon, the second section shows distribution of hamdryas baboon, and the third section deals with human-hamadryas baboon conflict in the study area.

\subsection{Population Size of Hamadryas Baboon}

The total count of hamadryas baboon individual in the study area for both wet and dry seasons is given in table 1 and 2 . The average number of hamadryas baboon observed in the entire study area was 1173 individuals during dry and wet season. The total number of hamadryas baboon counted was 1199 during the wet season, and 1146 during the dry season. There was no significant difference between wet and dry season count $\left(x^{2}=1.1978, d f=1, p>0.05\right)$.

Population size, sex, and age structure of hamadryas baboon during the wet season on each counting site are given in Tables 1. Similar results were obtained during consecutive counts at each counting sites and statistically no significant difference was found between consecutive counts. During the wet season count, there was significant difference in population size between adult males and adult females (d. $\mathrm{f}$ $\left.=1, x^{2}=33.76, \mathrm{p}<0.05\right)$. There was also significant difference in population size between sub-adult male and sub-adult female during Wet season count (d. $\mathrm{f}=1, x^{2}=17.8, p<$ $0.05)$. There was no significance difference in population size between juvenile male and female (d. $\mathrm{f}=1, x^{2}=$ $0.076, p>0.05)$.

In the total population of hamadryas baboon counted in the study area adult female comprised the largest portion. During the wet season, the individual count at Wote, Burkitu, and Wolda jebesa community forest was $16 \%$ adult male, $27 \%$ adult female, $12 \%$ sub adult male, $18 \%$ sub adult female, $10 \%$ juvenile male, $14 \%$ juvenile female, $3 \%$ infants.

Table 1. Population size, sex and age structure of hamadryas baboon during wet season in June 16-2017- September 1- 2017 in Wote, Burkitu and Wolda jebesa community forest of Gassera district $(M=$ male, $F=$ female, $S U I=$ sex unidentified, W/abboti= wolda abboti).

\begin{tabular}{|c|c|c|c|c|c|c|c|c|c|}
\hline \multirow{2}{*}{ Community forest } & \multirow{2}{*}{ Counting site } & \multicolumn{2}{|c|}{ Adult } & \multicolumn{2}{|c|}{ Sub-adult } & \multicolumn{2}{|c|}{ Juvenile } & \multicolumn{2}{|c|}{ Infants } \\
\hline & & M & $\mathbf{F}$ & M & $\mathbf{F}$ & M & $\mathbf{F}$ & SUI & Total \\
\hline \multirow[b]{2}{*}{ Wolda jebesa } & Guranda cliff & 54 & 90 & 45 & 76 & 35 & 43 & 10 & 353 \\
\hline & Jebesa cliff & 44 & 73 & 36 & 50 & 28 & 30 & 8 & 269 \\
\hline \multirow{3}{*}{ Wote chimo } & Ujuba cliff & 36 & 41 & 17 & 20 & 15 & 19 & 5 & 153 \\
\hline & W/ abboti clif & 28 & 61 & 20 & 32 & 18 & 38 & 7 & 204 \\
\hline & Sum & 64 & 92 & 37 & 52 & 33 & 57 & 12 & 357 \\
\hline \multirow[t]{3}{*}{ Burkitu } & Wote qarre cliff & 10 & 17 & 7 & 9 & 4 & 6 & 2 & 55 \\
\hline & Sum & 30 & 69 & 21 & 32 & 19 & 41 & 8 & 220 \\
\hline & Total Sum & 192 & 324 & 139 & 220 & 115 & 171 & 38 & 1199 \\
\hline
\end{tabular}

The wet season population size and age structure of hamadryas baboon in each site was compared. Accordingly, there was no significant difference in population size between male hamadryas baboon $(\mathrm{t}=3.26$, d. f. $=2$. $\mathrm{P}>0.05)$ and there was no significance difference in population size of female hamadryas baboon $(\mathrm{t}=3.818, \mathrm{~d} . \mathrm{f} .=2, \mathrm{p}>0.05)$. There was no significance difference in population size of sub-adult male hamadryas baboon $(\mathrm{t}=2.583, \mathrm{~d} . \mathrm{f} .=2, \mathrm{p}>0.05)$ and there was no significant difference in population size of sub-adult female hamadryas baboon $(\mathrm{t}=2.448, \mathrm{~d} . \mathrm{f}=2, \mathrm{p}>0.05)$. There was no significant difference in juvenile male hamadryas baboon ( $\mathrm{t}=2.954$, d. $\mathrm{f} .=2, \mathrm{p}>0.05)$ and there was significance different in population size of juvenile female hamadryas baboon $(t=6.170$, d. $f .=2, p<0.05)$. There was also significant difference in population size of infant hamadryas baboon $(\mathrm{t}=$ 4.359 , d. $f .=2, p<0.05$ ). The number of wet season adult male and female, sub-adult male and female, juvenile male and female as well as infants was compared. Based on that Wolda jebesa, Wote chimo and Burkitu have an abundant number of hamadryas baboon respectively. 
The dry season population size and age structure of hamadryas baboon in each site was compared. Accordingly, there was no significant difference in population size between male hamadryas baboon $(\mathrm{t}=3.264$, d. $\mathrm{f} .=2$. $\mathrm{P}>0.05)$ and there was no significance difference in population size of female hamadryas baboon $(t=3.963$, d. $f .=2, p>0.05)$. There was no significance difference in population size of sub-adult male hamadryas baboon $(\mathrm{t}=2.368, \mathrm{~d} . \mathrm{f} .=2, \mathrm{p}>0.05)$ and there was no significant difference in population size of sub-adult female hamadryas baboon $(\mathrm{t}=2.607, \mathrm{~d} . \mathrm{f} .=2, \mathrm{p}>0.05)$. There was no significant difference in the juvenile male hamadryas baboon

$(t=2.981$, d. $\mathrm{f} .=2, \mathrm{p}>0.05)$ and there was significantly different in population size of the juvenile female hamadryas baboon $(\mathrm{t}=6.179$, d. $\mathrm{f}=2, \mathrm{p}<0.05)$. There was also no significance difference in population size of the infant hamadryas baboon $(\mathrm{t}=3.713$, d. $\mathrm{f} .=2, \mathrm{p}<0.05)$.

Population size, sex and age structure of hamadryas baboon during the dry season is given in table 2 . Accordingly, there was significant difference in population size between adult male and adult female (d. f. $=1, x^{2}=$ $40.98 p<0.05)$. There was also significant difference in population size between sub-adult male and female during the dry season count $\left(\mathrm{df}=1, x^{2}=18.6, p<0.05\right)$. There was no significant difference in population size between juvenile male and female ( $\left.\mathrm{df}=1, x^{2}=11.32, p<0.05\right)$.

In the total population of hamadryas baboon counted in the study area adult female comprised the largest portion. During the dry season, the individual count at Wote, Burkitu, and Walda jebesa community forest was $15.8 \%$ adult male, $28 \%$ adult female, $11.5 \%$ sub adult male, $18.5 \%$ sub adult female, $9 \%$ juvenile male, $14 \%$ juvenile female, $2.5 \%$ infants.

Table 2. Population size, sex and age structure of hamadryas baboon during the dry season in February 16-May 30/2017 in Wote, Burkitu and Wolda jebesa community forest of Gassera district ( $M=$ male, $F=$ female, SUI=sex unidentified, W/abboti= wolda abbootii).

\begin{tabular}{|c|c|c|c|c|c|c|c|c|c|}
\hline \multirow{2}{*}{ Community forest } & \multirow{2}{*}{ Counting site } & \multicolumn{2}{|c|}{ Adult } & \multicolumn{2}{|c|}{ Sub-adult } & \multicolumn{2}{|c|}{ Juvenile } & \multicolumn{2}{|c|}{ Infants } \\
\hline & & $\mathbf{M}$ & $\mathbf{F}$ & $\mathbf{M}$ & $\mathbf{F}$ & $\mathbf{M}$ & $\mathbf{F}$ & SUI & Total \\
\hline \multirow{4}{*}{ Wolda jebesa } & Guranda cliff & 52 & 88 & 44 & 74 & 32 & 40 & 8 & 338 \\
\hline & Jebesa cliff & 41 & 72 & 36 & 48 & 26 & 28 & 6 & 257 \\
\hline & Sum & 93 & 160 & 80 & 122 & 58 & 68 & 14 & 595 \\
\hline & Ujuba cliff & 32 & 38 & 16 & 29 & 14 & 18 & 4 & 151 \\
\hline \multirow[t]{3}{*}{ Wote chimo } & W/ abboti clif & 27 & 60 & 18 & 31 & 16 & 37 & 6 & 195 \\
\hline & Sum & 59 & 98 & 34 & 60 & 30 & 55 & 10 & 346 \\
\hline & Burkitu cliff & 19 & 50 & 12 & 22 & 14 & 33 & 4 & 154 \\
\hline \multirow[t]{3}{*}{ Burkitu } & Wote qarre cliff & 10 & 17 & 6 & 8 & 4 & 5 & 1 & 51 \\
\hline & Sum & 29 & 67 & 18 & 30 & 18 & 38 & 5 & 205 \\
\hline & Total Sum & 181 & 325 & 132 & 212 & 106 & 161 & 29 & 1146 \\
\hline
\end{tabular}

Male and female ratio of hamadryas baboon based on the season is given in table 3 . Accordingly, the adult male female ratio was 1: 1.68 during the wet season and $1: 1.7$ during the dry season. Sub-adult male female ratio was $1: 1.6$ wet and 1: 1.6 during the dry season. Juvenile male and female ratio of hamadryas baboon was 1: 1.5 during both dry and wet season.

Table 3. Male-female ratio of hamadryas baboon based on season ( $M=$ male, $F=$ female).

\begin{tabular}{llll}
\hline \multirow{2}{*}{ Season } & Adult & Sub-adult & Juvenile \\
\cline { 2 - 4 } & M: F & M: $\mathbf{F}$ & M: F \\
\hline Wet & $1: 1.68$ & $1: 1.58$ & $1: 1.487$ \\
Dry & $1: 1.79$ & $1: 1.6$ & $1 ; 1.5$ \\
Total & $1: 1.7$ & $1: 1.59$ & $1: 1.5$ \\
\hline
\end{tabular}

Table 4. Size and age structure of hamadryas baboon based on seasons during 2016/2017 count (M=male, F= female, SUI= sex unidentified, $S$. adult $=$ sub-adult $)$.

\begin{tabular}{lllllllll}
\hline \multirow{2}{*}{ Season } & Adult & \multicolumn{4}{c}{ Sub adult } & \multicolumn{2}{c}{ Juvenile } & \multicolumn{2}{c}{ Infant } \\
\cline { 2 - 9 } & M & F & M & F & M & F & SUI & Total \\
\hline Wet & 192 & 324 & 139 & 220 & 115 & 171 & 38 & 1199 \\
Dry & 181 & 325 & 132 & 212 & 106 & 161 & 29 & 1146 \\
Average & 186.5 & 324.5 & 135.5 & 216 & 110.5 & 166 & 33.5 & 1172.5 \\
\hline
\end{tabular}

Size and age structure of hamadryas baboon in both dry and wet season is given in table 4. Accordingly, there was no significance difference in population size of adult male hamadryas baboon during wet and dry season (d. f.=1, $\left.x^{2}=0.32 p>0.05\right)$ and there was no significance difference in population size of adult female hamadryas baboon during wet and dry season $\left(\mathrm{df}=1, x^{2}=0.002 p>\right.$ $0.05)$. There was no significance difference in population of sab-adult male hamadryas baboon during wet and dry season count $\left(\mathrm{df}=1, x^{2}=0.18, p>0.05\right)$ and there was no significant difference in population size of sub-adult female hamadryas baboon during both season counts (d. f. $=1$, $x^{2}=0.148, p>0.05$ ). The Juvenile male and female was not show significant difference during both season with $\left(\mathrm{df}=1, x^{2}=0.366, p>0.05\right)$ and $\left(\mathrm{d} . \mathrm{f} .=1, x^{2}=0.302 p>\right.$ $0.05)$ respectively.

The wet season male female ratio of hamadryas baboon in each site is given in table 5. Accordingly the adult male female ratio was 1: 1.66 in Wolda jebesa, 1: 1.4 in Wote chimo and 1: 2.3 in Burkitu. Sub-adult male female ratio was 1: 1.55 in Walda jebesa, $1: 1.4$ in Wote chimo and $1: 1.5$ in Burkitu. The ratio of juvenile male and female was $1: 1.16$ in Walda jebesa 1: 1.7 in Wote chimo 1: 2.15 in Burkitu.

Table 5. Wet season male and female ratio of hamadryas baboon in Walda jabesa, Wote chimo and Burkitu community forest.

\begin{tabular}{llll}
\hline \multirow{2}{*}{ Community forest } & Adult & Sub-adult & Juvenile \\
\cline { 2 - 4 } & M: F & M: F & M: F \\
\hline Wolda jebesa & $1: 1.66$ & $1: 1.55$ & $1: 1.16$ \\
Wote chimo & $1: 1.4$ & $1: 1.4$ & $1: 1.7$ \\
Burkitu & $1: 2.3$ & $1: 1.5$ & $1: 2.15$ \\
Total & $1: 1.68$ & $1: 1.58$ & $1: 1.48$ \\
\hline
\end{tabular}


The dry season male and female ratio in each is given in table 6. Accordingly adult male female ratio was $1: 1.7$ in Walda jebesa, 1: 1.66 in Wote chimo and 1: 2.3 in Burkitu. Sub-adult male and female ratio was 1: 1.5 in Wolda jebesa, 1: 1.1.76 in Wote chimo and 1.: 1.66 in Burkitu. The ratio of juvenile male and female was 1: 1.17 in Walda jebesa, 1: 1.8 in Wote chimo and 1: 2.1 in Burkitu.

Table 6. Dry season male and female ratio of hamadryas baboon in Walda jabesa, Wote chimo and Burkitu community forest.

\begin{tabular}{llll}
\hline \multirow{2}{*}{$\begin{array}{l}\text { Community } \\
\text { forest }\end{array}$} & Adult & Sub-adult & Juvenile \\
\cline { 2 - 4 } & M: $\mathbf{F}$ & M: F & M: F \\
\hline Wolda jebesa & $1: 1.7$ & $1: 1.5$ & $1: 1.17$ \\
Wote chimo & $1: 1.66$ & $1: 1.76$ & $1: 1.8$ \\
Burkitu & $1: 2.3$ & $1: 1.66$ & $1: 2.1$ \\
Total & $1: 1.79$ & $1: 1.6$ & $1: 1.5$ \\
\hline
\end{tabular}

\subsection{Distribution of Hamadryas Baboon}

Hamadryas baboon is not evenly distributed across habitat. The habitat of hamadryas baboon was divided into four as forest, grassland; bush land and agricultural area. Table 7 below distributions of hamadryas baboon in Walda jebesa, Wote chimo and Burkitu community forest. In wolda jebesa community forest many hamadryas baboons was observed in forest and bush land area that is 200 of them were observed in the forest 310 was observed in bush land, 100 of them were observed in an open grass land, while 12 of them was observed in an agricultural area near the vicinity of community forest during wet season area in general 622 individual of hamadryas baboon was observed in Walda jebesa community forest. During the dry season 100 of them were observed in the forest, 88 of them was observed in bush land, 70 of them was observed in an open grass land, and 337 of them were observed in agricultural area when they were feeding in an agricultural area. In general 595 of individual of hamadryas baboon was observed in Walda jebesa during the dry season. The average number of hamadryas baboon in walda jebesa during both dry and wet season was 608.5.

In Wote chimo community forest 100 of them were observed in forest area, 188 were observed in bush land, 60 of the were observed in an open grass land, while 9 of them were observed in agricultural area in general 357 individuals of hamadryas baboon were observed during the wet season. During the dry season 60 of them were observed in forest, 50 of them were observed in bush land, 36 of them were found in open grassland while 200 of them were observed in agricultural area in general 346 individual of hamadryas baboon was observed. The total average of hamadryas baboon during both seasons in Wote chimo community forest was 351.5 .

In Burkitu community forest a total 220 individual of hamadryas baboon were observed during the wet season, of this 60 of them were observed in forest, 120 of them were observed in bush land, 30 of they were observed in open grass lad while 10 were observed in agricultural area. During the dry season of a total 205 individual of hamadryas baboon, 20 of them were observed in the forest, 50 of them were observed in bush land, 35 of them were observed in open grassland while 100 of them were observed in agricultural area. The average hamadryas baboon observed during both season was 212.5 in Burkitu community forest.

Table 7. Wet and dry season distribution of hamadryas baboon in Walda jebesa, Wote chimo and Burkitu community forest.

\begin{tabular}{|c|c|c|c|c|}
\hline \multirow{2}{*}{$\begin{array}{l}\text { Community } \\
\text { forest }\end{array}$} & \multirow{2}{*}{ Habitat types } & \multicolumn{3}{|c|}{$\begin{array}{l}\text { Number of observed hamadryas } \\
\text { baboon }\end{array}$} \\
\hline & & $\begin{array}{l}\text { Wet } \\
\text { season }\end{array}$ & $\begin{array}{l}\text { Dry } \\
\text { season }\end{array}$ & Average \\
\hline \multirow{5}{*}{ Walda jebesa } & Forest & 200 & 100 & 150 \\
\hline & Bush land & 310 & 88 & 199 \\
\hline & Grassland & 100 & 70 & 85 \\
\hline & $\begin{array}{l}\text { Agricultural } \\
\text { area }\end{array}$ & 12 & 337 & 174.5 \\
\hline & Sum & 622 & 595 & 608.5 \\
\hline \multirow{5}{*}{ Wote chimo } & Forest & 100 & 60 & 80 \\
\hline & Bush land & 188 & 50 & 119 \\
\hline & Grassland & 60 & 36 & 48 \\
\hline & $\begin{array}{l}\text { Agricultural } \\
\text { area }\end{array}$ & 9 & 200 & 104.5 \\
\hline & Sum & 357 & 346 & 351.5 \\
\hline \multirow{5}{*}{ Burkitu } & Forest & 60 & 20 & 40 \\
\hline & Bush land & 120 & 50 & 85 \\
\hline & Grassland & 30 & 35 & 32.5 \\
\hline & $\begin{array}{l}\text { Agricultural } \\
\text { area }\end{array}$ & 10 & 100 & 55 \\
\hline & Sum & 220 & 205 & 212.5 \\
\hline
\end{tabular}

There was no significance difference in distribution of hamadryas baboon in forest area in each counting site during both wet and dry season with $(\mathrm{t}=2.882, \mathrm{df}=2, \mathrm{p}>0.05)$ and $(\mathrm{t}=2.598, \mathrm{df}=2, \mathrm{p}>0.05)$ respectively. There was no significance in their distribution in bush land during wet season with ( $\mathrm{t}=3.706, \mathrm{df}=2, \mathrm{p}>0.05)$ and there was significant difference in their distribution in bush land during the dry season at $(\mathrm{t}=4.947, \mathrm{df}=2, \mathrm{p}<0.05)$. There was no significance difference in distribution of hamadryas baboon in grassland area during both wet and dry season count at $(\mathrm{t}=3.124, \mathrm{df}=2$, $\mathrm{p}>0.05)$ and $(\mathrm{t}=4.086, \mathrm{df}=2, \mathrm{p}>0.05)$ respectively. There was significance difference in their distribution in agricultural area during wet season at $(\mathrm{t}=11.717, \mathrm{df}=2, \mathrm{p}<0.05)$ and there was no significance difference in their distribution in agricultural area during the dry season at $(\mathrm{t}=4.086, \mathrm{df}=2$, $\mathrm{P}>0.05)$.

\section{Discussion}

The current study showed that hamadryas baboon has six sleeping cliffs. It is not common to observe hamadryas baboons and other species of baboon using trees as sleeping sites. The average number of hamadryas baboon was 1173 . The total number counted was 1199 during the wet season, and 1146 during the dry season. Some of study shows that the total number of hamadryas baboon from August 2011 to November 2013 was 1581 and 1845 respectively [19]. This difference is due to baboon drinking activity, which depends on season during the wet seasons, they do not have to go far to find pools of water and during the dry season, they frequent up to three permanent water holes [21]. 
There was no significant difference between wet and dry seasons. In the current study, the number of female hamadryas baboon was higher than male individual in all age groups. The study by shows that the proportion of female population was more in all age groups except for infants where sex identification was not possible [19]. This is important for their social organization and future population growth. In hamadryas baboon, high ranking dominant leader male, males had access to female. Where there are a large number of females, the prospect of the size would be good, unless resources become scarce and human interfere affect population trends. The ratio of adult malefemale, sub-adult male, female, juvenile male-female, showed the number of female individuals were higher than male individuals. The increase in the number of female can be good because in the social organization of hamadryas baboon, the dominant males can form one male unit, by having more than two females, their yang and sub-adult males. The density of hamadryas baboon was stated during both seasons.

The study by [19] showed that hamadryas baboons were distributed largely along the northern part of Awash National Park (ANP). The reason may be due to the availability of sufficient resources like forage, water holes, sleeping cliffs and trees that are used as sleeping sites. The current study showed that hamadryas baboons were distributed largely in Walda jebesa situated at the eastern tip, and next Wote chimo, which was situated at western tip of the community forest. The list number of hamadryas baboon was found at Burkitu community forest. This is due to the availability of the resource like food, water holes, sleeping cliffs. Woda jebesa is the more protected forest as compared to the others and have sufficient sleeping site as well as food and water for their survival. Burkitu community forest is highly disturbed by human intervention as road construction and baboon sleeping site and resources were distracted so limited resource limits their abundance. In case of wote chimo there were protected forest but some parts of the forest was disturbed by human activity as grazing, fire wood collection, plowing near the forest. The distribution of hamadryas baboon is highly influenced by the distribution and availability of the resource, specially food, water and sleeping cliffs [13]. Besides, hamadryas baboons require water holes and forage not far from their sleeping cliffs to minimize the distance traveled in obtaining water as well as forage resources. Comer reported that hamadryas baboon lives in semi-desert and savanna habitats, but their distribution in semi deserts is affected when resource availability decreases and hence, move to live in higher altitudes about $3000 \mathrm{~m}$.

Transformation of field and pasture land represents the main threat to the hamadryas baboon; it's only natural predator are striped Hayne, spotted hyena and African leopard who is still living in its area of distribution. The IUCN listed this species as "least concern" in 2008 [10]. There is no major range-wide threat at present, although locally, it may be at risk trough loss of habitat due to major agricultural expansion and irrigation project [7].

\section{Conclusion}

This study revealed that the population size of hamadryas baboon is almost the same during dry and wet season. There was no even distribution of hamadryas baboon across the study area due to insufficient food sources, water and sleeping cliff. Hamadryas baboon found in the study area were threatened due to human caused problems as forest clearance for fire fuels, fencing, building houses, and plowing near and in the forest as well. This made their uneven distribution in the study area. Some of the people catch and kill hamadryas baboon and they believe that hamadryas baboon has no economic benefit. This will have an impact on population size of hamadryas baboon. If the current trend continues, the number of hamadryas baboon would be at risk and even becomes locally instinct. Therefore, conservation measure should be taken to safe gourd the species of hamadryas baboon along with other wild animals as well.

The number of female Hamadryas baboon in all age group was higher than male individual this shows that as they are more productive. Concerning the number of Hamadryas baboon per counting site Walda jebesa hosts a higher number of Hamadryas baboon, Wolda Aboti in Wote chimo was the second. The least number of Hamadryas baboons was counted in the Burkitu community forest. This difference is due to the availability of food source, sleeping cliffs, and water sources which were highly available in Walda jebesa community forest as compared to the rest. The population size of Hamadryas baboon counted during wet season was higher in wet seasons than dry season this may be due to the difference in food and water source. During the wet season there is a plenty of the food and water sources so the does not go far in search of this resource. During the dry season they need to far in search of food and water resources.

Concerning the distribution of a Hamadryas baboon higher number of Hamadryas baboon was observed bush land, forest, and grass land respectively. The leas number of Hamadryas baboon was observed in agricultural areas. This was may be due to the availability of food source and their feeding behavior. Least numbers observed in agricultural land was due to the farmer's protection of their farm land from crop raider. But during the dry season large number of hamadyas baboon was observed in agricultural this is due to the scarcity of food sources in forest, bush land and grassland and agricultural area was free from protection by farmers and food source somewhat available in farmers plot.

\section{Recommendation}

Conservation of hamadryas baboon is depends on the availability of the resource as sleeping site, food, water holes and resource availability and abundance of hamadryas baboon is directly proportional. So to enhance and insure the existence of hamadryas baboon, local people, government, 
and other non-governmental institution should participate in conservation activity of the community forest.

\section{References}

[1] Chiarello, A. G. (2000). Density and Population Size of Mammals in Remnants of Brazilian Atlantic Forest. Conserve. Biol. 14: 1649-1657.

[2] Edward, E. (2010). And Frank, S. A. Victims Prospective of Lowes Monkeys (Cercopithecus campbelli lowei) crop raiding event in Ghana: A case of Boarbeng-Fiems Monkey Sanctuary. Journal of Biodiversity and Environmental Science. 2: $1-8$.

[3] Jacobs, M. J. and Schroeder, C. A. (2001). Impacts of Conflict on Biodiversity and Protected Areas in Ethiopia. Biodiversity Support Program. Washington, D. C. pp. 52-61.

[4] Yalden, D. W. (1983). The Extent of High Ground in Ethiopia Compared to the Rest Africa. SINET: Ethiop. J. Sci. 6: 35-39.

[5] Grubb, P. (2006). Ge-o species and Super Species in the African Primates Fauna. Primate. Conserve. 20: 75-78.

[6] Winney, B. J, Hammond, R. L, Macasero, B, Flores A, Boug A, Biquand V, Biquand S, Bruford MW (2004). Crossing the Red Sea phylogeography of the hamadryas baboon, Papio hamadryas hamadryas. Mol. Ecol. 13: 2819-2827.

[7] Zewdu Kifle, Gurja Belay and Afework Bekele, (2013). Population Size, Group Composition and Behavioural Ecology of Geladas (Theropithecus gelada) and Humangelada Conflict in Wonchit Valley, Ethiopia. Pakistan Journal of Biological Sciences, 16: 1248-1259.

[8] Hill, M. C. (2000). Confilict of Interest between people and Baboon: Crop Rading in Uganda International journal of primatology, Vo. 21, No. 2.

[9] Schreier, A. L. (2010). Feeding ecology, food availability and ranging patterns of wild hamadryas baboon at Filoha. Folia Primatol. 81: 129-145.

[10] Groves, C. P. Wilson, D. E. and Reeder, D. M. (2005). Mammal Species of the World: A Taxonomic and Geographic Reference (3rd ed.). Baltimore: Johns Hopkins University Press. pp. 166-167.

[11] Robbins, M. M. and Hohmann, G. (2006). Primate Feeding Ecology: An Integrative Approach. In: Feeding Ecology in
Apes and Other Primates: Ecological, Physical and Behavioral Aspects. pp. 1-10, (Hohmann, G. Robbins., M. M. and Boesch, C. eds). Cambridge University Press, New York.

[12] Shefferly, N. (2004). "Papio hamadryas" (On-line), Animal Diversity Web. Downloaded from http://animaldiversity.ummz.umich.edu/site/accounts/informat ion/Papio_hamadryas.html

[13] Biquand, S., Biquand-Guyot, V., Boug, A., Gautier, J. P. (1992). The distribution of Papio hamadryas in Saudi Arabia: Ecological correlates and human influence. Int. J. Primatol. 13: 223-243.

[14] Kate, K. (2012). Possible strategies/practices in reducing wild animal (Primate) crop raids in unprotected areas at Hoima, District, conduvted in two Sub-countries in Hoima District, Uganda.

[15] Gippoliti, S. and Ehardt, T. (2008). Papio hamadryas. In: IUCN 2008. IUCN Red List of Threatened Species. Retrieved 4 January 2009.

[16] Isabirye- Bassuta, G. M and Lwanga J. S (2008). Primate Population and Their interaction with changing habitat. Makere University. Kampala. Int. J. Primatol. 29: 35-48.

[17] IUCN (2010). http://www.iucnredlist.org/search. Accessed on 20 February 2013.

[18] Beehner, J. C., Bergman, G. and McCann, C. (2007). Population Estimate for Gelada (Theropithecus Gelada) Living in Around Semien Mountain National Park. J. Sci. 30: 149-154.

[19] Mesele Admassu, Yosef Mamo and Afawork Bekele (2014). Abundance of hamadryas baboon (Papio hamadryas hamadryas) and confilict with human in Awash National park. International Journal of Biodiversity Conservation. 6 (3): 200-209.

[20] Rosenbaum, B., O’Brien, T. G., Kinnaird, M. and Supriatna, J. (1998). Population Densities of Sulawesi Crested Black Macaques (Macacanigra) On Bacan and Sulawesi, Indonesia: Effects of Habitat Disturbance and Hunting. Am. J. Primatol. 44: 89-106.

[21] Kummer, H. (1968) Social Organisation of Hamdryas Baboons. A Field Study. Basel and Chicago: Karger, and University Press. 